STRUČNI ČLANAK

Aleksandar Matković

\title{
PROEKOLOŠKI KRIMINAL
}

\begin{abstract}
Apstrakt: Proekološki motivisana kriminalna delatnost poslednjih decenija doživljava veliku ekspanziju. Paralelno sa tendencijom povećanja ugroženosti celokupnog ekosistema, raste $i$ nivo svesti o neophodnosti očuvanja i sprečavanja njegove dalje degradacije, pri čemu se radikalna rešenja sve više primećuju kao odabrani metod suprotstavljanju remećenja balansa životne sredine. Cilj ovoga rada jeste doprinos tačnom određenju i definisanju protivpravnih aktivnosti motivisanih proekološkim pobudama, njihovo bliže predočavanje i prezentovanje na objektivnim, naučnim osnovama, te pokušaj popunjavanja praznina i ispravljanja nejasnoća primećenih u dosadašnjoj naučnoj i stručnoj praksi. U okviru predmetnog teksta izvode se zaključci o ukupnosti ovoga fenomena u svetlu njegove kriminalne, ali ne nužno $i$ terorističke prirode, ističu se $i$ sistematizuju protivpravni aspekti $i$ nude određeni modeli daljeg pravnog i opštedruštvenog ophođenja, uz sugestiju aktivnog praćenja $i$ proučavanja eko-kriminalnih tendencija, kao i razvijanja pojačane interakcije $i$ unapređenja komunikacije između društvenopolitičkih i naučnostručnih institucija, sa jedne, i eko-aktivističkih organizacija, sa druge strane.
\end{abstract}

Ključne reči: ekološki kriminal, eko-terorizam, ekologija, zaštita životne sredine.

\section{UVODNE NAPOMENE}

Odnos ekoloških pitanja i sa njima povezanih kriminalnih delatnosti je multiperspektivan. U kontekstu ugrožavanja ekosistema, može biti izdvojeno nekoliko različitih tipova pravno nedopuštenog delovanja, pri čemu se kao osnovni i najvažniji oblici ističu protivpravno uništavanje i oštećivanje prirodne sredine, sa jedne, i nezakonito delovanje upereno protiv takvog (legalnog ili nelegalnog) ponašanja, sa druge strane. Otuda je proučavanje ove vrste uslovljeno konkretizacijom istraživanja i preciziranjem relevantnih eko-kriminalnih segmenata koji se nastoje obuhvatiti. Opseg ovoga rada biće ograničen isključivo na protivpravno delovanje motivisano ekološkim pobudama, u cilju zaštite i sprečavanja degradacije prirodnog okruženja.

Master pravnik, doktorand Pravnog fakulteta Univerziteta Union u Beogradu e-mail: al.matkovic@gmail.com 


\section{Pojam PROEKološKog KRIMINALA}

\subsection{DEFINICIJA I OPŠTE KARAKTERISTIKE}

$\mathrm{Na}$ početku rasprave o proekološkom kriminalu, neophodno je bliže odrediti šta će sve pomenutim pojmom biti označavano u okviru ovoga rada. Takođe, potrebno je razjasniti određene nejasnoće i dileme u vezi sa problemom determinacije. U tom cilju, prvo će biti izložene neke od karakterističnih definicija ovoga fenomena. Budući da se tradicionalna teorija uglavnom služi pojmom eko-terorizam u cilju prikazivanja celokupnog spektra ovde analiziranog kompleksa, poslužićemo se definicijama koje se odnose na navedenu pojavu.

Jedno od mogućih određenja eko-terorizma jeste ono koje ga opisuje kao terorizam ili sabotažu koji se izvršavaju u ime ekoloških pitanja; nasilje sprovođeno u cilju ostvarenja političkih ili društvenih ciljeva ekologa. ${ }^{1}$ Sledeća definicija ukazuje na višeznačnost analiziranog pojma. Naime, u pitanju je sabotaža namenjena ometanju aktivnosti koje se smatraju štetnim za životnu sredinu; međutim, navedeni termin može se odnositi i na oblik političkog terorizma usmeren na oštećenje protivnikove prirodne sredine. ${ }^{2}$ Sledeća formulacija na prilično precizan i obuhvatan način određuje ovu pojavu. Po njoj, eko-terorizam predstavlja uništenje ili pretnju uništenjem životne sredine od strane država, grupa ili pojedinaca u cilju zastrašivanja ili prinuđivanja vlade ili građana; takođe, skup krivičnih dela počinjenih protiv kompanija ili vladinih organizacija sa namerom sprečavanja ili ometanja aktivnosti koje se mogu smatrati štetnim po prirodnu sredinu. Ovako postavljen, termin eko-terorizam može označavati tri različite vrste aktivnosti. Prva je tzv. antisistemsko nasilje (odnosno, nasilje upereno protiv aktuelnih političkih struktura), poznato i kao bioterorizam, čiji karakteristični oblici mogu obuhvatiti, na primer, kontaminaciju vode, vazduha i zemljišta, upotrebu bioloških agenasa, odnosno biološkog oružja i sl. Drugi oblik, uobičajeno nazivan i ekološki rat, podrazumeva namerno i protivpravno uništavanje, eksploatisanje i modifikovanje prirodne sredine kao strategijsko sredstvo u ratu i drugim oružanim sukobima, uključujući i građanske ratove. Ovoj odrednici zamerili bismo to što prevazilazi okvire terorističkih akcija i zahvata forme ratnih sukoba, koje svakako ne bi trebalo mešati sa prvopomenutima. Konačno, treće moguće značenje termina eko-terorizam obuhvata aktivnosti nasilnog karaktera pojedinih ekoloških organizacija i udruženja. ${ }^{3} \mathrm{FBI}$ je ovu pojavu definisao

\footnotetext{
1 Ecoterrorism - The Free Dictionary, (http://www.thefreedictionary.com/ecoterrorism).

2 Ecoterrorism - Merriam-Webster Dictionary, (http://www.merriam-webster.com/dictionary/ecoterrorism).

3 Ecoterrorism - Encyclopaedia Britannica, (http://www.britannica.com/EBchecked/ topic/765758/ecoterrorism).
} 
kao upotrebu ili pretnju upotrebom nasilja kriminalne prirode, najčešće simboličkog karaktera, protiv ljudi i imovine, od strane ekološki orijentisanih, podnacionalnih grupa, radi ostvarenja ekološko-političkih ciljeva. ${ }^{4}$

Kao što se lako da primetiti, pojam eko-terorizam je obuhvatan i njegova značenja mogu biti veoma različita, a ponekad i protivrečna. Predmet ovoga rada, u skladu sa već istaknutim, predstavlja samo onaj aspekt protivpravnih akata koji je uperen protiv organizacija $i$ lica odgovornih $z a$ narušavanje ekosistema i remećenje njegovog prirodnog balansa, prema pokretnoj i nepokretnoj imovini povezanoj sa navedenim licima, organizacijama i njihovim delatnostima, te prema svim aktivnostima koje za posledicu imaju ugrožavanje životne sredine. Stoga, ograničivši na ovaj način polje delovanja rada Proekološki kriminal, izneta formulacija može biti ponuđena i kao definicija ukupnosti ovde proučavanog fenomena.

$\mathrm{Na}$ ovom mestu potrebno je izvesti kritičku analizu samog termina eko-terorizam. Iako je ovaj naziv široko prihvaćen za sabotaže i diverzije navedenog tipa, čini se da je njegova upotreba često nedovoljno osnovana. Radikalne akcije ekoloških aktivista (kako će na narednim stranama biti pokazano), u najvećem broju slučajeva uperene su isključivo prema imovini, dok ubedljiva većina organizacija i pojedinaca izričito osuđuje ugrožavanje ljudskih života. Štaviše, priroda izvršenih imovinskih delikata veoma često svojim karakterom i obimom ne dopušta klasifikaciju ove vrste. Otuda se sa razlogom može postaviti pitanje da li je opravdano izjednačavati sve diverzantske akcije ovoga tipa sa pojedinim ekstremnim slučajevima masovnog ugrožavanja života, zdravlja i opšte sigurnosti velikog broja ljudi, koji se uobičajeno podvode pod okrilje terorističkih akata uopšte. Aktivisti ekoloških organizacija ističu i sledeći argument koji, barem delimično, nije bez osnova. Oni ukazuju na činjenicu da je pravi „eko-terorizam” zapravo bespoštedno uništavanje prirodnih resursa i ekosredine, protiv dobrobiti čitave populacije i na uštrb celovitog ekosistema, u cilju zadovoljenja ličnih interesa veoma uskog broja lica, a ne odbrana i sprečavanje degradacije prirodne sredine u svrhu zajedničkog dobra. ${ }^{5} \mathrm{Na}-$ stavljajući kritičku analizu, treba primetiti da je nauka iznedrila posebnu odrednicu - environmentalni terorizam, kojom se označavaju terorističkosabotažne aktivnosti koje imaju za cilj oštećenje ili uništenje prirodne sre-

4 Jarboe, J., 2002, The Threat ofEco-Terrorism, (http://web.archive.org/web/20080311231725/ http://www.fbi.gov/congress/congress02/jarboe021202.htm).

5 Uporediti: Smith, R., Ecoterrorism?: A Critical Analysis of the Vilification of Radical Environmental Activists as Terrorists, Environmental Law, 38 (2), (http://law.lclark. edu/law_reviews/environmental_law/past_issues/volume_38/38_2.php).

Vidal, J., 2008, The Green Scare, The Guardian, (http://www.theguardian.com/environment/2008/apr/03/greenbuilding.ethicalliving). 
dine i njenih resursa,${ }^{6}$ čime je, čini se, prikazana terminološka konfuzija i višeznačnost već $u$ dobroj meri kultivisana. Ta okolnost sasvim sigurno predstavlja dodatni razlog za preispitivanje osnovanosti dalje upotrebe prvopomenute, široko i nedovoljno precizno postavljene odrednice. Sledeći, izuzetno značajan argument tiče se same prirode delikata koji potpadaju pod okrilje ekoloških radikalnih aktivnosti. Iako eko-teroristički akti upereni protiv života i zdravlja ljudi jesu mogućnost koja stoji na raspolaganju radikalnim eko-aktivistima, dosadašnja kriminalna praksa je pokazala da su oni u ubedljivoj manjini spram ostalih oblika nedopuštenog ponašanja ovoga tipa. Dalje, dok pojedina krivična dela izvršavana u ime ekoloških pitanja svojom prirodom i obimom mogu biti kvalifikovana kao dela koja ugrožavaju sigurnost i bezbednost većeg broja lica, te samim tim (uz određene rezerve) eventualno i kao teroristička dela, ne treba zaboraviti da velika većina prestupa ove vrste ne prelazi profil lakših oblika krivičnih dela manjeg obima delovanja i nižeg stupnja društveno-pravne opasnosti. Konačno, veliki broj akcija radikalnih ekoloških aktivista svojim karakteristikama ne prevazilazi pozitivno-pravni opseg prekršaja. Na osnovu svega rečenog, može biti zaključeno da je upotreba termina eko-terorizam samo delimično osnovana i, uopšte uzev, nedovoljno precizna. Stoga će u ovom radu biti ponuđen drugačiji model definisanja, ostvaren putem pojma proekološkog kriminala. Osim toga, za drugi osnovni aspekt eko-kriminalnog dejstvovanja uopšte, odnosno za ponašanje koje obuhvata ugrožavanje životne sredine i prirodnog balansa ekosistema, takođe može biti formulisana nova odrednica - antiekološki kriminal. Ovakvom terminološkom specijalizacijom i polarizacijom ključnih modela eko-kriminalnog ponašanja stvaraju se osnovane pretpostavke za izbegavanje dosadašnje konfuzije i prevazilaženje nejasnoća u razumevanju i proučavanju ukupnosti predmetnih pojava.

\subsection{NASTANAK I IDEOLOŠKE POSTAVKE}

Proekološki kriminal pronašao je svoju inspiraciju u konceptima ekološkog pokreta, prevashodno njegove radikalne frakcije, čija popularnost je značajno porasla šezdesetih godina XX veka. ${ }^{7}$ Rani aktivisti nisu pokazivali jasan ideološki program i doslednu svest o tačno utvrđenim ciljevima delovanja. Akcije organizovane početkom sedme decenije XX veka bile su u najvećoj meri odraz kontrakulture koja je zahvatila zapad-

6 Detaljnije o ovoj temi videti npr. u: Schwartz, D., 1998, Environmental Terrorism: Analyzing the Concept, Journal of Peace Research, 35, pp. 483-496;

Baechler, G., Environmental Degradation and Violent Conflict: Hypotheses, Research Agendas, and Theory-building, u: Suliman, M., (ur.), 2000, Ecology, politics, and violent conflict, London, Zed Books, pp. 76-112.

7 Up. Long, D., 2004, Ecoterrorism (Library in a Book), New York, Facts on File, p. 14 i d. 
ni svet krajem šezdesetih godina. Međutim, već tada se među istaknutijim učesnicima počinje oblikovati i usvajati filozofska osnova koja će inspirisati kasnije aktiviste i pružiti učesnicima konkretno formulisanu i argumentovanu svrhu njihovog delovanja. Među činiocima koji su inspirisali nastanak ovakve ideološko-filozofske baze ističu se marksističke postavke, doktrine socijalizma, ideje feminizma, istočnjački religijskofilozofski sistemi i dr. Koristeći elemente navedenih koncepata, radikalni ekolozi su usvojili polazište prema kome su kapitalizam, patrijarhalno društvo i judeohrišćanska tradicija odgovorni za degradaciju prirode, usled činjenice da se svaka od navedenih pojava, prema mišljenju pobornika ove ideje, na sebi svojstven način, u značajnoj meri udaljava od životnog stila usklađenog sa prirodom. Iako u raspoloživoj literaturi nije moguće pronaći izričito navođenje onih osobina pomenutih socio-privrednih, porodično-funkcionalnih i religijsko-društvenih sistema koje se kose sa načelima ekologije i opstanka ekosistema, iznećemo nekoliko zapažanja koja bi mogla rasvetliti smisao navedenih tvrdnji. Kao što je poznato, interesi kapitalističke privrede neretko su korenito suprotstavljeni predispozicijama očuvanja prirodnog staništa, o čemu svedoče brojni primeri tokom celokupnog istorijata postojanja i razvoja ovog privrednog uređenja. Otuda se prvi argument, uzevši u obzir predloženo tumačenje, čini razjašnjenim uz visok procenat sigurnosti. Prelazeći na pitanje patrijarhalne društvene zajednice, možemo sugerisati sledeće objašnjenje. Matrijarhat, kao oblik porodičnog i društvenog uređenja koji je prethodio patrijarhalnom, bio je suštinski opredeljen idejom ženskog primata u velikom broju sfera - između ostalog, u odnosu ka svetu prirode uopšte. Isto tako, razmatrajući religijsko-mitološke sisteme drevnih epoha, čitavi koncepti prirode, plodnosti i nastajanja zasnivali su se u velikoj meri na osobenostima ženskog roda, odakle su i shodna božanstva veoma često personifikovana u liku žene. Prelaskom na patrijarhalni režim, ovakav pristup bio je korenito izmenjen, u čemu se, čini se, može pronaći adekvatno objašnjenje uzroka navedenih tvrdnji. Konačno, u judeohrišćanskoj tradiciji, pojam žene i njen opšti teorijski i praktični položaj takođe gube svoj pređašnji uticaj i status, čime se ova ideja može smatrati produžetkom pitanja odnosa između matrijarhalnog i patrijarhalnog uređenja.

Za kraj, može biti navedeno nekoliko osnovnih pravaca unutar na ovaj način nastale, environmentalističke filozofije i ideologije. To su: duboka ekologija, eko-feminizam, socijalna ekologija i bioregionalizam. ${ }^{8}$

8 Long, D., 2004, pp. 19-20;

Liddick, D., 2006, Eco-terrorism: Radical Environmental and Animal Liberation Movements, Westport, Greenwood Publishing Group, p. 14 i d. 


\subsection{OBLICI ISPOLJAVANJA}

Dosadašnja praksa protivpravne, ekološki motivisane borbe pokazuje raznovrsne pristupe i metode diverzantskog delovanja. Stoga ću ovde pokušati da ih klasifikujem i bliže predočim. ${ }^{9}$

Podmetanje požara predstavlja jedan od najčešće korišćenih, pravno nedopuštenih metoda ekoloških radikalnih aktivista. Ovim putem nastoji se da se ošteti, odnosno uništi pokretna i nepokretna imovina. Zbog prilagodljivosti ovog metoda, moguće je primeniti ga u veoma raznorodnim situacijama. Mete podmetača požara često su stambeni i poslovni objekti, prodajna mesta terenskih vozila, određena postrojenja, specifična mehanizacija i sl.

Tehnika poznatija kao tree spiking označava taktiku ukucavanja sitnih šiljaka u stabla drveća za koja se očekuje da bi mogla biti obuhvaćena programom krčenja. Oštećenje testera i drugih sredstava upotrebljavanih za seču i obradu takođe može predstavljati jedan od vidova upotrebe ove strategije.

Tree sitting spada u najmanje invazivne metode i sastoji se u zaposedanju stabala drveća planiranog za seču. U okviru ove taktike, eko-aktivisti privremeno nastanjuju krošnje pojedinog drveća u cilju sprečavanja njihove eksploatacije. Ova tehnika može biti iscrpljena već samim činom nastanjivanja stabala, ali se u okviru naprednijeg pojavnog oblika može paralelno voditi i legalan, sudski vid borbe za ostvarenje konkretnog ekološkog cilja, pri čemu tada tree sitting ima za cilj sprečavanje procesa eksploatacije pre donošenja sudske presude povodom predmetnog spora.

Upotreba eksplozivnih naprava jeste jedan od najekstremnijih vidova borbe radikalnih environmentalista. Željeni cilj, sfera primene i vrsta dobara koja se ugrožavaju ovim putem u velikoj meri se podudaraju sa opisanom taktikom podmetanja požara. Osim toga, dosadašnja eko-kriminalna praksa poznaje i slučajeve bombaških napada na život i telo pojedinaca, čime se proširuje opseg vrednosti ugroženih ovakvim protivpravim delovanjem.

Nedopušteni akti ugrožavanja života i tela ljudi mogu se ispoljiti u vidu ubistva, nanošenja lakih, odnosno teških telesnih povreda, ugrožavanja lične sigurnosti itd., pri čemu se metodi i oblici izvršenja podudaraju sa klasičnim formama izvršenja korelirajućih delikata.

Uništavanje, odnosno oštećivanje vozila, mašina i ostalog materijala korišćenog prilikom krčenja šuma i drugih aktivnosti usmerenih na remećenje prirodnog staništa jeste značajan aspekt eko-sabotaže, pri čemu se kao modus operandi može pojaviti i neko od već navedenih taktičkih rešenja.

9 U raspoloživoj literaturi primetan je nedostatak sistematičnog i na jednom mestu objedinjenog pokušaja klasifikovanja metoda proekološkog kriminalnog delovanja. Za temeljan prikaz, videti: Liddick, D., 2006, pp. 69-81. 
Destruktivne aktivnosti usmerene ka saobraćajnicama koje prolaze kroz prirodne celine većeg značaja takođe su deo dosadašnje sabotažne prakse.

Kada je u pitanju zaštita životinjskog sveta u izvornom staništu, kao primer metoda diverzantskog delovanja ovoga usmerenja može biti istaknuto uništavanje opreme i infrastrukture namenjene za lov.

Vodene površine, a naročito mora i okeani, zavređuju visok stepen pažnje ekstremnih ekoloških aktivista, pri čemu postoji značajna raznorodnost među potencijalnim metama napada i ciljevima koji se nastoje ostvariti. Kao početni model klasifikacije možemo ponuditi dve osnovne kategorije. To su akti usmereni na sprečavanje ili sabotiranje zagađivanja i remećenja prirodnog balansa vodenog ekosistema uopšte, sa jedne, i akti koji imaju za cilj osujećivanje eksploatacije prvenstveno životinjskog sveta ovoga staništa, sa druge strane.

Navedenim primerima lista pojavnih oblika ekološki motivisanog protivpravnog delovanja svakako nije iscrpljena, no pomenuti primeri mogu značajno doprineti boljem razumevanju prirode i suštine analizirane pojave.

Ono što je veoma važno napomenuti jeste činjenica da se svim iznetim sredstvima borbe, pored pomenutih ciljeva, takođe nastoji postići efekat zastrašivanja i prevencije, kao i podizanje ekološke svesti i skretanje pažnje javnosti na pojedina pitanja koja se tiču očuvanja i zaštite životne sredine.

\section{EKO-KRIMINALNI AKTIVIZAM I NJEGOVA DEJSTVA}

\subsection{ORGANIZACIJE I POJEDINCI}

Pojavni oblici ekološki motivisanog kriminala manifestuju se kroz delovanje pojedinaca ili grupa, pri čemu se, kako će u narednim redovima biti pokazano, granica između pomenute dve kategorije neretko teško uočava. Dok u okviru individualnog aktivizma pojedinac nedvosmisleno deluje isključivo u svoje ime, dotle se akti članova određenog radikalnog ekološkog udruženja smatraju i aktima predmetne organizacije. Međutim, osobine pojedinih eko-organizacija (posebno nepostojanje zvanične strukture, ustanovljene hijerarhije, vođstva, formalizovanog članstva i sl.) čine ovu podelu uslovnom i u velikoj meri je relativizuju.

\section{Green Peace}

Green Peace predstavlja nevladinu environmentalističku organizaciju sa predstavništvom u preko četrdeset zemalja i sa međunarodnim koordinirajućim telom u Amsterdamu. U pitanju je jedan od prvih organizovanih i omasovljenih pokušaja ekološkog aktivizma odnosnog tipa. Nastalo u rasponu između kasnih šezdesetih i ranih sedamdesetih godina XX 
veka, ovo udruženje usmerava svoje ciljeve na različita ekološka pitanja poput globalnog zagrevanja, uništavanja šumskog pokrivača, upotrebe nuklearne energije, genetskog modifikovanja i dr. Među metodima delovanja, javljaju se direktna akcija, lobiranje i istraživačka delatnost. Ova organizacija osuđuje agresivne oblike direktne akcije, upotrebljavane od strane ekstremnije orijentisanih udruženja, usled čega svoje ciljeve nastoji ostvariti mirnim sredstvima. ${ }^{10}$

\section{Sea Shepherd Conservation Society}

Sea Shepherd Conservation Society osnovao je 1977. godine pod nazivom Earth Force Society Pol Votson, ranije član Green Peace-a. To je neprofitna organizacija fokusirana na delovanje u pravcu očuvanja morskih i okeanskih celina. U svojim aktivnostima članovi koriste agresivne vidove intervencije, uz obrazloženje da, po njihovom mišljenju, javno mnjenje ne pokazuje interesovanje za rešavanje istaknutih ekoloških problema, usled čega se nasilni metodi nameću kao jedino rešenje. Ono što čini značajan element strategije udruženja Sea Shepherd, jeste energično delovanje na širenju i popularisanju njihovih ciljeva i akcija putem medija. Sedište se nalazi u mestu Frajdej Harbor, u američkoj saveznoj državi Vašington. ${ }^{11}$

\section{Earth First!}

Earth First! je radikalna organizacija posvećena očuvanju životne sredine, čiji su temelji postavljeni 1979, dok je formalno organizovanje usledilo naredne godine. Udruženje je internacionalnog karaktera, sa frakcijama ustanovljenim u velikom broju zemalja rasprostanjenih na različitim kontinentima. Nastalo je u jugozapadnom regionu Sjedinjenih Američkih Država, kao reakcija na tadašnju aktuelnu politiku ekoloških organizacija u pogledu tekućih projekata zaštite prirodnih regiona SAD. Smatrajući aktivizam tada postojećih udruženja za zaštitu životne sredine neprihvatljivim, osnivači organizacije Earth First! istakli su parolu beskompromisne borbe za očuvanje ekosistema i opredelili se za energično delovanje metodom direktne akcije. Brojne zapažene ekološke sabotaže i diverzije izveli su članovi ove organizacije. ${ }^{12}$

10 Long, D., 2004, pp. 23-25;

Green Peace - zvanična internet prezentacija, (http://www.greenpeace.org/international/en/).

11 Long, D., 2004, pp. 25-27;

Sea Shepherd Conservation Society - zvanična internet prezentacija, (http://www.seashepherd.org/).

12 Long, D., 2004, pp. 29-33,

Earth First! Journal, (http://earthfirstjournal.org/). 


\section{Animal Liberation Front}

Animal Liberation Front ili, kako se često skraćeno navodi, ALF, jeste obuhvatni pojam za različite grupe i individualne aktiviste uključene $\mathrm{u}$ borbu za oslobođenje i zaštitu životinja. Udruženje je nastalo u Engleskoj 1976. godine, dok su njegova priroda i struktura internacionalnog karaktera. Specifičnost Fronta za oslobođenje životinja ogleda se u primeni leaderless resistance metoda, odnosno strategije pružanja otpora bez formalne organizovanosti udruženja, njegovog zvaničnog rukovodstva i hijerarhijske ustrojenosti. Potencijalnim aktivistima je ostavljena sloboda da se, po sopstvenom nahođenju, priključe pokretu otpora delujući na način koji samostalno izaberu, pri čemu značajan koordinirajući uticaj ima zvanični priručnik ALF-a o oblicima i vidovima delovanja. Usled toga, identitet članova pojedinih ogranaka i samostalnih aktivista ostaje nepoznat većini pripadnika pokreta, čime se postižu brojne prednosti. Naime, ovakva strategija omogućava veliku vitalnost organizacije i visok stepen sigurnosti njenih članova, te efikasnu prevenciju otkrivanja komponenti ALF-a od strane policije. Aktivnosti Fronta obuhvataju oslobađanje životinja iz istraživačkoeksperimentalnih laboratorija i napad na ovakve ustanove i druge s njima povezane naučne centre, oslobađanje životinja stacioniranih na farmama, kao i uništavanje i oštećivanje farmi, klanica, tehnike i drugih strateških ciljeva. Ipak, za ovaj rad od interesa su one akcije ALF-a koje se tiču zaštite životinja u prirodnoj sredini, kao i očuvanja njihovog staništa. ${ }^{13}$

\section{Earth Liberation Front}

Earth Liberation Front, skraćeno ELF, predstavlja svojevrsni ogranak ALF-a. U pitanju je kolektivni naziv za autonomne grupe ili pojedince koji učestvuju u ostvarenju zajedničkih ekoloških ciljeva. Front oslobođenja Zemlje nastao je 1992. godine u Engleskoj, od kada se globalno raširio i učvrstio svoje međunarodne pozicije. Budući da je proistekao iz matičnog okrilja ALF-a, sve što je rečeno za njega u pogledu strukture i osnovnih načela organizovanja i metoda delovanja odnosi se i na ELF frakciju. Kako se navodi u zvaničnom programu Fronta, svrha njegovog postojanja jeste sprečavanje eksploatisanja i destrukcije životne sredine upotrebom radikalnih metoda. Fokusirajući se na ekonomsku sabotažu, odnosno sprovodeći uništavanje imovine odgovornih korporacija i drugih organizacija uključenih $\mathrm{u}$ iskorišćavanje prirodnih resursa, aktivisti ELF-a nastoje potisnuti zloupotrebu životne sredine motivisanu željom za profitom i drugim materijalnim beneficijama zainteresovanih strana. Ovo udruženje preuzelo je odgovornost za veoma veliki broj vandalskih, sabotažnih i terorističkih akcija širom sveta, čime se svrstava u sam vrh najaktivnijih i najdelotvornijih ekoloških

13 Animal Liberation Front - zvanična internet prezentacija, (http://www.animalliberationfront.com/). 
ekstremističkih grupacija. Shodno rečenom, FBI je u martu 2001. godine okarakterisao Earth Liberation Front kao najveću pretnju domaćem terorizmu na području Amerike. U skladu sa time, ELF se, od svih postojećih radikalnih ekoloških organizacija, najviše i najčešće dovodi u vezu sa ranije objašnjenim, klasično shvaćenim pojmom „eko-terorizam”. ${ }^{14}$

\subsection{PRIKAZ ODABRANIH PROTIVPRAVNIH SLUČAJEVA}

Da bi razumevanje prirode pravno nedopuštenog delovanja ekstremističkih ekoloških aktivista bilo potpunije, potrebno je upoznati se sa praktičnim aspektima pojedinih, do sada izvršenih delikata ove kategorije. Stoga će u narednim redovima u osnovnim crtama biti opisano nekoliko karakterističnih akata iz eko-kriminalne prakse, čija struktura na slikovit način doprinosi stvaranju jasne predstave o ovde analiziranoj pojavi.

Kao što je ranije napomenuto, podmetanje požara jedan je od najzastupljenijih metoda protivpravnog delovanja motivisanog ekološkim pobudama.

U oktobru 1998. godine, aktivisti ELF-a podmetnuli su požar u velikom američkom ski-centru Vejl. Tom prilikom su uništeni ili oštećeni jedan restoran, kamp, sedište ski-patrole i četiri ski-lifta, dok je ukupna šteta procenjena na dvanaest miliona američkih dolara. ${ }^{15}$

U San Dijegu, u američkoj državi Kalifornija, 1. avgusta 2003. godine, u podmetnutom požaru uništena je konstrukcija stambenog objekta u izgradnji, a šteta je procenjena na najmanje dvadeset miliona američkih dolara. Time se ovaj incident svrstava u jedan od najvećih i najdestruktivnijih kriminalnih projekata radikalnih ekoloških aktivista. Na mestu zločina ostavljena je dvanaest stopa dugačka zastava sa potpisom ELF-a i porukom koja je sadržavala pretnju daljim sabotažnim delovanjem na ovome lokalitetu (natpis If you build it, we will burn it). ${ }^{16}$

U naselju Haj Bridž, u američkoj državi Vašington, 3. marta 2008. godine, nepoznata lica zapalila su četiri luksuzne kuće izgrađene u okviru

14 Earth Liberation Front, (http://www.earth-liberation-front.com/ i http://www.originalelf.com/).

15 Brooke, J., 1998, Group Claims Responsibility For Blazes At Vail Resort, The New York Times, (http://www.nytimes.com/1998/10/22/us/group-claims-responsibilityfor-blazes-at-vail-resort.html);

Sullivan, R., 1998, The Face of Eco-Terrorism, The New York Times, (http://www.nytimes. com/1998/12/20/magazine/the-face-of-eco-terrorism.html?pagewanted=all\&src=pm);

Barnard, J., 2006, Two pleaded guilty in 1998 ELF ski resort fire, The Seattle Times, (http://seattletimes.com/html/localnews/2003477514_webresortfire14.html).

16 Coronado, R., 2003, San Diego Fire, Earth First! Journal, (http://www.geog.ucsb. edu/ sweeney/g108/lectures/ELF5.pdf);

Cart, J., Morin, M., 2003, ELF action in San Diego, LA Times, (http://la.indymedia. org/news/2003/08/75488.php); 
projekta Seattle Street of Dreams. Tri objekta su u potpunosti uništena, dok je vatrogasna služba uspela da delimično sačuva četvrtu kuću. Ukupna šteta procenjena je na oko sedam miliona američkih dolara. Izvršioci su na ogradi jedne od izgorelih kuća auto-lakom ispisali poruke koje su ukazivale na njihovo protivljenje izgradnji ovih objekata, pri čemu su naveli organizaciju ELF kao potpisnika ovoga akta. Ipak, iako su aktivisti ELF-a glavnoosumnjičeni, istraga još uvek nije utvrdila odgovorne za ovo krivično delo, pri čemu se spominje da postoji i određena sumnja da je čitav zločin zapravo insceniran u cilju zloupotrebe i neovlašćenog pribavljanja novčane koristi na ime osiguranja uništenih i oštećenih objekata. ${ }^{17}$

Govoreći o akcijama usmerenim na sprečavanje komercijalnog ribolova, lova na kitove i drugih srodnih aktivnosti, sabotiranje procesa eksploatacije i, naročito, oštećenje i uništavanje plovila i ostale opreme ima najzapaženiju ulogu. U vezi sa poslednjim, Sea Shepherd Conservation Society smatra se odgovornim za potapanje većeg broja brodova ovoga tipa, pri čemu se među prvim metama njihovih napada ističu kitolovci Sierra (potopljen 1980. u luci u Lisabonu), Ibsa I i Ibsa II (potopljeni 1981. u španskoj luci u Vigi), dva kitolovca uništena 1986. godine na Islandu, u blizini Rejkjavika, kada je oštećena i stanica za lov na kitove itd. ${ }^{18}$

Nasuprot imovinskim deliktima, slučajevi direktnog napada na život i telo ljudi daleko su malobrojniji. Među njima veoma zapaženo mesto zauzima primer dr Teodora Kačinjskog. Kačinjski, (rođen 1942), uhapšen je 3. aprila 1995. godine zbog sumnje da je u periodu između 1978. i 1995. godine sprovodio terorističku kampanju motivisanu ekološkim razlozima i uperenu protiv moderne tehnologije i tehnološkog progresa. Kačinjskom se pripisuje da je u tom razdoblju izvršio brojna podmetanja i slanja poštom eksplozivnih naprava kućne izrade, usled čega je usmrćeno troje, a ranjeno dvadeset troje ljudi, mahom stručnjaka za visoku tehnologiju. ${ }^{19}$

Foundation for Biomedical Research - Top 20* List of Illegal Actions by Animal and Eco-Terrorists 1996-2006, (http://www.universityofcalifornia.edu/news/animalresearch/top20incidents.pdf).

17 Whitely, P., 2008, Suspicious fires destroy 3 Street of Dreams homes, damage 1, in Snohomish County, The Seattle Times, (http://seattletimes.com/html/localnews/2004256586_webdreamsfire03m.html);

Smith, D., Holtz, J., 2009, A year after arsonists hit Street of Dreams, ruins remain, HeraldNet, (http://www.heraldnet.com/article/20090301/NEWS01/703019847);

Green, S., 2010, 'Street of Dreams' homebuilder pleads guilty to stealing sales tax, The Seattle Times, (http://seattletimes.com/html/localnews/2012598460_homebuilder12m.html).

18 Pogledati dokument Sea Shepherd Violent History, (http://www.icrwhale.org/eng/history.pdf).

19 Za pojedinosti o dr Teodoru Kačinjskom, njegovom manifestu protiv tehnološkog društva i njegovim bombaškim napadima, videti: Graysmith, R., 1997, Unabomber: A Desire to Kill, New York, Berkley Publishing; 
Tehnika tree spiking doživela je najintenzivnije kritike nakon incidenta iz 1987. godine u američkoj državi Kalifornija, kada je radnik Džordž Aleksander ozbiljno povređen nakon što je klin (za koji se pretpostavlja da je bio postavljen od stane eko-aktivista) dospeo u dodir sa testerom kojom je Aleksander rukovao. Iako je ova tehnika nakon toga masovno osuđivana i odbačena od strane dela radikalnih eko-aktivista, treba istaći da je ovo, na osnovu raspoloživih saznanja, do sada jedini globalno poznat incident ove vrste. Osim toga, sami propagatori istovrsnih ekoloških diverzija ističu da je razlog upotrebe ovoga metoda isključivo sprečavanje seče drveća, bez namere da se prouzrokuje povreda. $U$ prilog rečenom, neki zagovornici i izvršioci tree spiking-a od tada su uveli praksu obeležavanja i ostavljanja napomena unutar na ovaj način modifikovanih šumskih regiona. ${ }^{20}$

Počeci prakse tree sitting-a vezuju se za slučaj iz 1978. godine na Novom Zelandu, koji se ujedno smatra i prvim zvaničnim aktom ove vrste. Pomenuta akcija sprovedena je u regionu koji je, zahvaljujući uspešnosti akcije, proglašen zaštićenom park-šumom Pureora. ${ }^{21}$ Sa druge strane, prvi zabeleženi slučaj u Americi dogodio se 1985. godine, a izvršio ga je Mikal Jakubas u šumi Vilamet u Oregonu. ${ }^{22}$

\section{OCENA PRIRODE PROEKOLOŠKOG KRIMINALA I SMERNICE ZA KRIVIČNO-PRAVNO I DRUŠTVENO REAGOVANJE}

Upravo izloženim postavkama učinjen je pokušaj preciznijeg i jasnijeg definisanja i predočavanja fenomena proekološkog kriminala, čime je ujedno ostvaren jedan od primarnih ciljeva ovoga rada. Osim toga, nakon

Kaczynsky, T. (The Unabomber), 2005, The Unabomber Manifesto: Industrial Society and It's Future, Minneapolis, Filiquarian Publishing;

Labaton, S., 1993, Clue and \$1 million Reward In Case of the Serial Bomber, The New York Times, (http://www.nytimes.com/1993/10/07/us/clue-and-1-million-reward-incase-of-the-serial-bomber.html);

Lardner, G., Adams, L., 1996, To Unabomb Victims, a Deeper Mystery, The Washington Post, (http://www.washingtonpost.com/wp-srv/national/longterm/unabomber/ bkgrdstories.victims.htm).

20 Rowell, A., 1996, Green Backlash. London, Routledge, p.153;

Bandow, D., 1990, Ecoterrorism: The Dangerous Fringe of the Environmental Movement, (http://www.heritage.org/research/reports/1990/04/ecoterrorism-the-dangerous-fringe-of-the-environmental-movement).

21 New Zealand Native Forests Restoration Trust - About the Trust, (http://www.nznfrt. org.nz/about-trust).

22 Fountain, H., 2006, Rising Above the Environmental Debate, The New York Times, (http://www.nytimes.com/2006/06/18/weekinreview/18basic.html?_r=0). 
analize, moguće je izvesti određene dodatne zaključke i uočiti pravilnosti, što bi trebalo doprineti celovitijem razumevanju predmetne pojave.

Kao što je pokazano, naziv proekološki kriminal čini se kao najoptimalniji za definisanje šarolikog skupa pravno nedopuštenog ponašanja povezanog sa ekološkim aktivizmom. Uvažavajući širinu i raznolikost same oblasti, te uzimajući u obzir iznete manjkavosti i nepreciznosti do sada upotrebljavanih odrednica, predložen je ovaj termin u nadi da će on na najprimereniji način odgovoriti postavljenim zahtevima. $U$ vezi sa navedenim, a posebno $\mathrm{u}$ kontekstu obuhvatnosti materije, smatram da je, $\mathrm{u}$ daljem razvoju naučne i stručne analize proekološkog kriminaliteta, uputno ostaviti prostor za naknadnu specijalizaciju proučavanja unutar užih sekcija istovrsnih protivpravnih akata. Stoga, iako se na ovome mestu, usled prostornih i tematskih ograničenja, ne mogu detaljnije opservirati sugerisana potklasifikacija i sa njom povezana pitanja, ipak može biti iznet predlog naziva nekolicine osamostaljenih kategorija unutar matične sfere proekološkog kriminaliteta. Proučavanje predmetnog kriminala moglo bi se, u zavisnosti od vrste prestupa i njegove težine, dodatno specijalizovati formiranjem sledećih podgrupa: proekološki vandalizam, proekološka diverzija, odnosno sabotaža i, u krajnjem stupnju, kada to priroda i težina pojedinih delikata dopušta, proekološki terorizam (u užem značenju, koje je obrazloženo i zastupano u ovom radu).

Potrebno je dodatno naglasiti neophodnost uvažavanja različitosti vrste i vrednosti ugroženih dobara, kao i sa njima povezanog, nejednakog stepena opasnosti koju svaka konkretna kategorija kriminalnog ponašanja povlači za sobom. Ovaj pristup dolazi u obzir kako kod klasifikovanja i upoređivanja eko-kriminalnih aktivnosti međusobno, tako i pri njihovom vrednovanju naspram terorističkog, sabotažnog i vandalističkog delovanja uopšte. Slikovit primer može biti prikazan na polju razvrstavanja terorizma, gde se, po nekim modelima klasifikacije, eko-terorizam svrstava među najveće opasnosti za društveni i državni poredak. Uprkos vidljivim tendencijama u ovome smeru, mišljenja sam da je neosnovano stvarati jedinstvenu katerogiju potencijalno terorističkog delovanja koja bi obuhvatila i ujedinila najteže oblike direktnog ataka na ljudske živote, opštu sigurnost $\mathrm{i}$ bezbednost, izvedene od strane otvoreno militarističkih organizacija, sa jedne, i akte ekološki motivisanog napada na striktno imovinske ciljeve, sprovođene od najčešće deklarisano pacifističkih, u odnosu na ugrožavanje ljudskih života izričito osuđujućih udruženja, sa druge strane.

Nastavljajući objedinjavanje izvedenih zaključaka, može se kao nesporna izneti činjenica da svaki oblik ovde analiziranog nedopuštenog ponašanja zaslužuje adekvatan krivično-pravni tretman. Vraćajući se na tradicionalno pitanje odnosa prava i morala, neumitno se mora izvesti 
zaključak da se svako od navedenih delovanja treba podvrći pravnom ophođenju, uprkos sadržaju pratećih okolnosti, ukoliko je sukobljeno sa važečim pravnim normama. Nezavisno od ličnih uverenja i logičkih, moralnih i drugih argumenata, u ambijentu aktuelne, u savremenom svetu široko prihvaćene pravne doktrine i sa njom povezane ideologije pravne sigurnosti, neophodno je pridržavati se slova i smisla zakona ukoliko se nastoji da se održi model pravne zajednice i pravno uređenog poretka. Međutim, ovo ni na koji način ne treba da bude shvaćeno kao sugerisanje svesnog ignorisanja potencijalnih pravnih propusta i manjkavosti zakonodavstva. Svaki napor za unapređenje pozitivnog prava usmerenog ka pitanjima ekologije i zaštite životne sredine, uočavanjem i pravilnim razumevanjem mogućih slabosti, protivrečnosti i drugih nedostataka, te iniciranjem njihovog ispravljanja, izuzetno je poželjan, usled čega je potrebno afirmisati i ohrabrivati ovakav kritički pristup unutar naučne i stručne javnosti. Iako aktuelni pravni poredak obavezuje na saglasno ponašanje i primenjivanje propisa, predmetni stručnjaci trebalo bi da kontinuirano i sa posebnom pažnjom rade na njihovom korigovanju i poboljšavanju, osobito uzevši u obzir globalni interes i najviši stepen važnosti pravilnog regulisanja obuhvaćenih pitanja. Ove postavke, uopšteno gledano, naročito dolaze do izražaja u ambijentu specifičnih kriminalnih ispoljavanja kod kojih je granica između pravnog i moralnog, te pravnog i pravičnog neretko pomućena, pri čemu se ekološki motivisan kriminal nameće kao jedan od najkarakterističnijih predstavnika rečene kategorije. Stoga je prilikom razmatranja i regulisanja iznetog, neophodno nastupati krajnje oprezno i obazrivo, uz punu svest o prirodi i značaju analizirane materije.

$\mathrm{Na}$ ovom mestu će biti dodato nekoliko zapažanja koja se tiču efekata i rezultata pažljivog proučavanja i postizanja pravilnog razumevanja ciljeva ostvarivanih izvršavanjem proekoloških delikata. Kao što je dobro poznato i samo po sebi razumljivo, u krivično-pravnoj, kriminološkoj i kriminalističkoj sferi, proučavanjem uzroka, okolnosti i specifičnosti izvršenja različitih kategorija pravno nedopuštenog ponašanja pospešuju se izgledi za efikasno suzbijanje i prevenciju date kategorije kriminaliteta. Otuda, već po ovom početnom osnovu, proekološki kriminalitet ne bi smeo predstavljati izuzetak. Međutim, od daleko veće je važnosti razumevanje i ispravno tumačenje specifičnog spleta okolnosti i osobenosti koji odlikuje ovu kriminalnu tendenciju. Uzevši u obzir esencijalnost ekoloških pitanja za, u krajnjoj liniji, opstanak čitavog ekosistema, te samim tim i civilizacije, više je nego opravdano pridavati pun značaj svakom indikatoru o potencijalnom ugrožavanju životne sredine i pratiti tendencije ekoloških organizacija i njihovih akcija. Na taj način, analizom uzroka, okolnosti i dinamike izvršavanja pojedinih eko-aktivi- 
stičkih akata, značajno se može unaprediti informisanost o relevantnim ekološkim pitanjima, koja nužno, direktno ili indirektno, dotiču svakog pripadnika globalne zajednice. Ovakvom argumentu moglo bi se, ne sasvim bez razloga, prigovoriti da se, na taj način, potencijalno posredno ohrabruje eko-kriminalno ponašanje. Međutim, takvoj eventualnoj zamerci suprotstavlja se druga, značajna okolnost. Eko-kriminal, kako je pokazano, osim konkretnim, akutnim interesima, teži i opštem skretanju pažnje javnosti na pojedine lokalne ili globalne ekološke probleme, te povećanju ukupne ekološke svesti stanovništva. Otuda ne bi trebalo olako zanemarivati na ovaj način ostvaren izvor relevantnih informacija o negativnim ekološkim tendencijama, od kojih značajan procenat poseduje obeležja protivpravnog ponašanja. Sa druge strane (i ponovo u vezi sa navedenom tendencijom usmeravanja pažnje javnosti), društveno-političko, naučno i stručno ignorisanje ekološki motivisanog kriminalnog ponašanja veoma lako može voditi ka njegovoj daljoj ekspanziji i uvećanju kako kvantiteta delikata tako i ekstremizma u pogledu odabira ciljeva i sredstava izvršenja, u pojačanom nastojanju da se ekološkim pitanjima prida očekivana pažnja. Imajući to u vidu, više je nego osnovano pretpostaviti da bi ostvarivanje izvesne, po svemu sudeći neformalizovane interakcije na relaciji radikalno ekoloških aktivista, sa jedne, i društvenih predstavnika, naučnih i stručnih lica, sa druge strane, moglo dovesti do smanjenja izvora ekstremističkog nezadovoljstva, te samim tim i umanjenja kvantiteta i težine njihovih kriminalnih akata. Posmatrano iz suprotne perspektive, iako metodi ekoloških ekstremista nedvosmisleno nisu primereni poretku pravne države, njihovi ciljevi, kako je izneto, ponekad mogu biti jasan indikator postojanja ekološki neprihvatljivih okolnosti, čije blagovremeno korigovanje predstavlja interes celokupne, neretko i globalne zajednice. Stoga već samo praćenje tendencija eko-kriminala i pravilno razumevanje njegovih osobina, uz objektivno i stručno vrednovanje celokupnog zbira relevantnih okolnosti, efektivno može doprineti kako smanjenju obima i intenziteta nedopuštenog delovanja ove vrste i njegovoj prevenciji tako i ostvarenju ekoloških interesa najrazličitije vrste na lokalnom i globalnom nivou. Konačno, uspešnim prevazilaženjem, odnosno ublažavanjem raskoraka između društvenopolitičkih zvaničnika, stručnjaka i naučnih delatnika, sa jedne, i proekokriminalnih aktivista, sa druge strane, otvorila bi se realna perspektiva za povećanje prisutnosti i zastupljenosti drugih, društveno i pravno prihvatljivih modela ekološkog reagovanja na negativne tendencije povezane sa kompleksom životne sredine, te samim tim i za umanjenje ekološki motivisanog kriminalnog delovanja. 


\section{LITERATURA}

1. Animal Liberation Front - zvanična internet prezentacija, (http://www.animalliberationfront.com/).

2. Baechler, G., Environmental Degradation and Violent Conflict: Hypotheses, Research Agendas, and Theory-building, u: Suliman, M., (ur.), 2000, Ecology, politics, and violent conflict, London, Zed Books.

3. Bandow, D., 1990, Ecoterrorism: The Dangerous Fringe of the Environmental Movement, (http://www.heritage.org/research/reports/1990/04/ecoterrorism-thedangerous-fringe-of-the-environmental-movement).

4. Barnard, J., 2006, Two pleaded guilty in 1998 ELF ski resort fire, The Seattle Times, (http://seattletimes.com/html/localnews/2003477514_webresortfire14.html).

5. Brooke, J., 1998, Group Claims Responsibility For Blazes At Vail Resort, The New York Times, (http://www.nytimes.com/1998/10/22/us/group-claims-responsibility-for-blazes-at-vail-resort.html).

6. Cart, J., Morin, M., 2003, ELF action in San Diego, LA Times, (http://la.indymedia. org/news/2003/08/75488.php).

7. Coronado, R., 2003, San Diego Fire, Earth First! Journal, (http://www.geog.ucsb. edu/ sweeney/g108/lectures/ELF5.pdf).

8. Ecoterrorism - Encyclopaedia Britannica, (http://www.britannica.com/EBchec$\mathrm{ked} /$ topic/765758/ecoterrorism).

9. Ecoterrorism - Merriam-Webster Dictionary, (http://www.merriam-webster.com/ dictionary/ecoterrorism).

10. Ecoterrorism - The Free Dictionary, (http://www.thefreedictionary.com/ecoterrorism).

11. Earth First! Journal, (http://earthfirstjournal.org/).

12. Earth Liberation Front, (http://www.earth-liberation-front.com/ i http://www.originalelf.com/).

13. Foundation for Biomedical Research - Top 20* List of Illegal Actions by Animal and Eco-Terrorists 1996-2006, (http://www.universityofcalifornia.edu/news/animalresearch/top20incidents.pdf).

14. Fountain, H., 2006, Rising Above the Environmental Debate, The New York Times, (http://www.nytimes.com/2006/06/18/weekinreview/18basic.html?_r=0).

15. Graysmith, R., 1997, Unabomber: A Desire to Kill, New York, Berkley Publishing.

16. Green Peace - zvanična internet prezentacija, (http://www.greenpeace.org/international/en/).

17. Green, S., 2010, 'Street of Dreams' homebuilder pleads guilty to stealing sales tax, The Seattle Times, (http://seattletimes.com/html/localnews/2012598460_homebuilder12m.html).

18. Jarboe, J., 2002, The Threat of Eco-Terrorism, (http://web.archive.org/web /20080311231725/http://www.fbi.gov/congress/congress02/jarboe021202.htm.

19. Kaczynsky, T. (The Unabomber), 2005, The Unabomber Manifesto: Industrial Society and It's Future, Minneapolis, Filiquarian Publishing.

20. Labaton, S., 1993, Clue and \$1million Reward In Case of the Serial Bomber, The New York Times, (http://www.nytimes.com/1993/10/07/us/clue-and-1-millionreward-in-case-of-the-serial-bomber.html). 
21. Lardner, G., Adams, L., 1996, To Unabomb Victims, a Deeper Mystery, The Washington Post, (http://www.washingtonpost.com/wp-srv/national/longterm/unabomber/bkgrdstories.victims.htm).

22. Liddick, D., 2006, Eco-terrorism: Radical Environmental and Animal Liberation Movements, Westport, Greenwood Publishing Group.

23. Long, D., 2004, Ecoterrorism (Library in a Book), New York, Facts on File.

24. New Zealand Native Forests Restoration Trust - About the Trust, (http://www.nznfrt.org.nz/about-trust).

25. Rowell, A., 1996, Green Backlash. London, Routledge.

26. Schwartz, D., 1998, Environmental Terrorism: Analyzing the Concept, Journal of Peace Research, 35.

27. Sea Shepherd Conservation Society - zvanična internet prezentacija (http://www. seashepherd.org/).

28. Sea Shepherd Violent History, (http://www.icrwhale.org/eng/history.pdf).

29. Smith, D., Holtz, J., 2009, A year after arsonists hit Street of Dreams, ruins remain, HeraldNet, (http://www.heraldnet.com/article/20090301/NEWS01/703019847).

30. Smith, R., „Ecoterrorism”?: A Critical Analysis of the Vilification of Radical Environmental Activists as Terrorists, Environmental Law, 38 (2), (http://law.lclark. edu/law_reviews/environmental_law/past_issues/volume_38/38_2.php).

31. Sullivan, R., 1998, The Face of Eco-Terrorism, The New York Times, (http:// www.nytimes.com/1998/12/20/magazine/the-face-of-eco-terrorism. html? pagewanted=all\&src $=\mathrm{pm})$.

32. Vidal, J., 2008, The Green Scare, The Guardian, (http://www.theguardian.com/ environment/2008/apr/03/greenbuilding.ethicalliving).

33. Whitely, P., 2008, Suspicious fires destroy 3 Street of Dreams homes, damage 1, in Snohomish County, The Seattle Times, (http://seattletimes.com/html/localnews/2004256586_webdreamsfire03m.html).

\section{PRO-ENVIRONMENTAL CRIME}

\section{Aleksandar Matković}

\section{SUMMARY}

One of the objectives of this paper is to precisely define the phenomenon of pro-environmentally motivated crimes, as well as to provide its objectified presentation and analysis. Instead of the term eco-terrorism, which dominated the literature so far, the author offers the term proenvironmental crime, explaining that it far better suits the diverse nature of the specter of illegal environmental activities. As narrower categories, categories of pro-environmental vandalism, pro-environmental diversion, i.e. sabotage and pro-environmental terrorisms (in its narrower sense) are formulated, together with suggestions for further organisation and specialisation of research within those. The author introduces the additional 
term of anti-environmental crime to define illegal activities with consequences in endangering and disturbing the balance within the ecosystem. Argumentation is provided in favor of re-evaluation of the level of danger to the society, which is the result of environmental activism, particularly bearing in mind the declared pacifist approach of the majority of environmental associations, whose programs explicitly condemn assaults to physical integrity, opposed to numerous militarist, classic terrorist organisations, both national and international. At the same time, the readers' attention is drawn to shortcomings of unification of pro-environmental crime, without taking into account the differences between particular illegal acts, as well as the character and value of endangered goods. Speaking of positive law aspects, the author identifies an unambiguous necessity to equally treat each environmental activist tendency which confronts the legal norms in force, as well as to prosecute the persons responsible, in the interest of the rule of law and legal certainty. On the other hand, the author supports the idea of reassessment and further improvement of relevant legislation, particularly having in mind the complex nature and immense importance of environmental issues in the context of the future of our global community. The essential importance of preservation of the environment provokes additional examination of possibilities for future relations between state authorities and scientists and experts, on one side, and environmental activists, on the other, while the author concludes that every improvement in understanding the nature and characteristics of current environmental issues would have multiple benefits. Systematic research and proper understanding of disturbances in the ecosystem and dangers towards it, including monitoring and analysis of tendencies in pro-environmental crime, seam as steps forward in the struggle to preserve the balance in global environment, while it would at the same time reduce the reasons for further use of eco-criminal techniques, which, finally, creates an additional perspective towards legally acceptable methods of environmental activism.

Key words: environmental crime, eco-terrorism, ecology, environmental protection.

Dostavljeno Redakciji: 2. oktobra 2013. god.

Prihvaćeno za objavljivanje: 18. novembra 2013. god. 